\title{
El pintor que escribe en un muro de papel: David Alfaro Siqueiros en la Revista Multicolor de los Sábados (1933)
}

\section{The Painter Who Writes on a Paper Wall: David Alfaro Siqueiros in Revista Multicolor de los Sábados (1933)}

\section{Resumen \\ El artículo se centra en la participación de David Alfaro Siqueiros en la Revista Multicolor de los Sábados (Argentina). Por un lado, se estudiará la apropiación y resignificación que hace esta publicación periódica de la idea predominante en la propuesta de Siqueiros de "sacar el arte a la calle"; y por otro, se analiza el modo en que en la producción literaria del muralista mexicano, su propuesta política queda opacada por los condicionamientos de la prensa masiva.}

Palabras claves

Publicaciones Periódicas, David Alfaro Siqueiros, Vanguardia política, Redes Culturales

\begin{abstract}
The article analyses David Alfaro Siqueiros participation in Revista Multicolor de los Sábados (Argentina). On the one hand, it studies the way this periodic publication apropriates and resignificate the predominant idea on Siqueiros Art Theory: take the art out of the museums to the street. On the other hand, this paper explores the way in which the literary production of the Mexican muralist overshadows his political proposal because of the conditions of mass press.
\end{abstract}


Entre los años de su exilio iniciado en 1932, David Alfaro Siqueiros, muralista y militante activo del partido comunista mexicano, llevó consigo y difundió sus propuestas estéticas y sus consignas políticas en ciudades como Los Ángeles, Montevideo y Buenos Aires, a la vez que estableció redes culturales e intelectuales. El 25 de mayo de 1933 el artista desembarcó en Argentina junto con la uruguaya Blanca Luz Brum e inmediatamente reforzó y encauzó la discusión sobre el rol del arte en el contexto político y social, instaurando en el ámbito intelectual local la polémica entre "arte puro" y "arte comprometido". Este debate circuló entre distintas publicaciones periódicas en las que escritores y pintores respondieron dando su punto de vista (Contra, Claridad, Poesía, Gaceta de Buenos Aires, diario Crítica, diario El Mundo) y continuó incluso después de la partida del artista, tras ser deportado a los siete meses de su llegada.

Pocos meses después, en agosto de 1933, el masivo y sensacionalista diario Crítica sacaba a la calle un suplemento ilustrado de literatura bajo la dirección de Jorge Luis Borges y Ulyses Petit de Murat: la Revista Multicolor de los Sábados (1933-1934). La presencia de imágenes a todo color y la publicación de textos literarios fueron dos particularidades que definieron a esta publicación y le dieron una identidad propia frente a otras revistas y suplementos contemporáneos. Siqueiros participó del primer número con una ilustración que con el tiempo se convirtió en uno de los rasgos representativos del modelo de intervención pública del suplemento y además publicó otros tres textos literarios en números posteriores. La participación de este artista en la Revista Multicolor puede leerse como un caso que permite indagar con mayor detalle un aspecto aún no suficientemente explorado pero muy presente en sus páginas: las articulaciones entre vanguardia política y prensa masiva, y más específicamente, entre compromiso y fruición.

En este artículo se sostiene que en la Revista Multicolor se reutilizaron algunas de las propuestas de este artista, articulándolas con los intereses de la industria cultural. Se analizará, por un lado, el modo en que el suplemento de 
CATEDRAL TOMADA: Revista de crítica literaria latinoamericana / Journal of Latin American Literary Criticism El pintor que escribe en un muro de papel: David Alfaro Siqueiros en la Revista Multicolor de los Sábados (1933)

Crítica se apropió de la idea de "sacar el arte a la calle", presente en la propuesta de las conferencias argentinas de Siqueiros, y la resignificó en la creación de lo que puede identificarse como un "mural en la revista"; por otro, se estudiará en el modo en que la producción escrita del muralista mexicano entró en tensión con los condicionamientos de la prensa masiva.

\section{La Revista Multicolor de los Sábados: un muro de papel}

Al llegar a Argentina David Alfaro Siqueiros proyectaba dar tres conferencias en la Asociación Amigos del Arte, ${ }^{1}$ radicada en la ciudad de Buenos Aires. De entre ellas, llegó a pronunciar sólo dos, en las que proponía una estética revolucionaria, anti-institucional y accesible a las masas. Elena Sansinena de Elizalde, presidente de esa sociedad, clausuró la tercera charla y la exposición por temor a un virulento ataque por parte del sector más reaccionario de la derecha local que, no sólo cuestionó los dichos de Siqueiros desde sus publicaciones periódicas -principalmente revistas como Crisol y Bandera Argentina-, ${ }^{2}$ sino que amenazó con cometer atentados contra las obras del artista mexicano expuestas en Buenos Aires. ${ }^{3}$ Ante el conflicto con esta reconocida institución, varias publicaciones periódicas argentinas se hicieron eco de la polémica; entre ellas, las que mayor

${ }^{1}$ Cfr. P. Artundo y M. Pacheco (2008) Amigos del arte, 1924-1942. Buenos Aires, MALBAFundación Constantini y V. G. Meo Laos (2007) Vanguardia y renovación estética: Asociación Amigos del Arte (1924-1942) Buenos Aires: Ediciones CICCUS.

${ }^{2}$ Crisol fue uno de los matutinos de derecha más radicales de Argentina, fue fundado por Enrique Osés y apareció entre 1932 y 1944. Bandera Argentina. Diario Nacionalista, dirigido por Juan Carulla y Santiago Díaz, se publicó entre 1932 y 1945.

${ }^{3}$ Así anunciaba una nota del 3 de julio de 1933 en el diario El Mundo el comienzo de la polémica que signó los primeros años de la década de 1930: "La llegada del pintor Siqueiros produjo cierta balumba de cosas; comenzó en drama y terminó en sainete, en pochade. Ya 'Crisol' dio la primera versión, la más borroso del caso Siqueiros-Nalé Roxlo [...]. Pero Siqueiros, pintor, dialéctico, agitador social, produjo indudablemente sanas reacciones: los pintores decidieron estudiar, porque fueron sorprendidos en un estado de inocencia casi paradisíaco. Y los escritores tuvieron el placer de comprobar que buena parte de los plásticos ignoran en absoluto las más elementales leyes de estética" (1933 6). Como indica esta caracterización, Siqueiros no sólo era artista sino también agitador, estudioso. 
respaldo y promoción dieron a la iniciativa del muralista mexicano fueron las revistas Contra, Signo y el diario Crítica.

Contra. La revista de los francotiradores (1933), dirigida por el poeta Raúl González Tuñón, desde su tercer número publicó diversos textos de opinión sobre la figura de Siqueiros y sus propuestas artísticas y políticas, así como también reprodujo algunas de sus obras y el fragmento final de una conferencia pronunciada un año antes en el John Reed Club de Los Ángeles, en la que el muralista describía su propuesta de una plástica de agitación y propaganda dialéctico-subversiva antiburguesa y proponía tres instancias para la implementación de un arte comunista hasta la consolidación de una sociedad sin clases en la que finalmente se pudiera ejecutar un “arte puro". ${ }^{4}$ En la misma línea ideológica, la asociación Signo (1933), bajo la dirección de Leonardo Estarico, que contaba con una peña y una revista, publicó notas sobre Siqueiros y organizó una charla abierta al público en la que aquel pudo, finalmente, exponer las principales ideas de la conferencia que no le permitieron dar en Amigos del Arte. En el encuentro de Signo participaron colaboradores de Contra y Crítica, ${ }^{5}$ que circulaban por las tres publicaciones.

Los artículos del diario, por su parte, ponían el foco en la polémica entre Siqueiros y Amigos del Arte. En el periódico se publicó la noticia de este altercado con los tintes sensacionalistas que lo caracterizaban, tal como lo dejan ver los artículos "David A. Siqueiros es un caballo troyano en los Amigos del Arte: Su exposición de pintura será custodiada por el cuerpo de bomberos" (6 de junio de

\footnotetext{
${ }^{4}$ La conferencia dada por Siqueiros en Los Ángeles se tituló "Los vehículos de la pintura dialécticosubversiva", el texto publicado en Contra recibió el nombre de "Plástica dialéctico-subversiva".

5 Así se señalaba en Contra: "Siqueiros habló en 'Signo', mostrando una vez más su conocimiento y su coraje. Su conferencia, de "preguntas y respuestas" fue una formidable arremetida contra los pasatistas y la burguesía. Siqueiros pulverizó a sus adversarios, ¡los pulverizó!, y nadie se atrevió a seguir discutiéndole. Tenía Siqueiros las manos llenas de argumentos definitivos, de clara y terminante dialéctica. Ojalá hayan aprendido algo los pintores" (1933 2). Esta charla tuvo repercusiones también en publicaciones conservadoras como Bandera Argentina: diario nacionalista, en cuyo ejemplar de junio publicó la nota "La banda comunista en Signo", en la que despectivamente de describía el éxito que había tenido la charla entre los escritores de izquierda y los colaboradores de Crítica: "Es inicuo y desdoroso que en la Avenida de Mayo [donde se ubicaba el hotel Castelar, lugar donde se llevó a cabo la reunión] se realicen reuniones públicas de esta naturaleza comunista, de íntegra factura comunista, en la que no faltó el trapo rojo, reunión auspiciada por los plumíferos analfabetos del diario 'Crítica', escritorzuelos comunistas, degradados, que confesaron en 'Signo' en voz alta su credo siniestro”' (23/06/1933).
} 
1933) y "Los enemigos del arte han prohibido la segunda conferencia del profesor Siqueiros" (15 de junio). Además de difundir los acontecimientos que sucedieron en torno al debate, el diario tomó posición a favor del muralista, denostando a la asociación presidida por Elena Sansinena de Elizalde, frente a la cual daba relevancia a la palabra del artista y a su obra. El diario se ofrecía como un espacio abierto para que éste publicara artículos como "Un llamamiento a los plásticos argentinos" (Critica, 2 de junio de 1933), en el que daba a conocer las particularidades de su propuesta y arengaba a los pintores locales a tomar una posición política con respecto al arte. Invitó, asimismo, al muralista, a colaborar en la Revista Multicolor de los Sábados como ilustrador y como escritor. Este texto puede ser considerado como el manifiesto argentino del mexicano en el que se destaca una posición compartida con otros artistas de la izquierda local: la pintura muralista se concebía como una entre otras formas de llegar a las masas y quitar la obra del museo, de sacarla a la calle.

Si para Siqueiros la obra tenía un valor por su presencia en lugares concurridos por el mayor número de personas, y, por tanto, por su más amplia divulgación, el suplemento de Critica no sólo se presentaba como un espacio que contribuía a la difusión de los textos e ilustraciones de éste y otros artistas entre un público numeroso, sino que convertía en slogan uno de los principales postulados del manifiesto escrito por el muralista mexicano: en los ejemplares de la semana anterior a su publicación el diario promocionaba la salida de la Revista Multicolor como "La mejor lectura para el más numeroso público", exaltando una política de democratización del acceso al arte y a la lectura. Esta misma política formaba parte también de la publicidad del periódico, que ya desde sus comienzos se autoproclamaba como el "diario del pueblo". Mediante este tipo de estrategias, en la Revista Multicolor se articulaban de manera inesperada los propósitos de la industria cultural (entretener a los fines de obtener un beneficio económico) con algunos de los formulados por la vanguardia política (la accesibilidad del arte a las masas). 
La conocidísima primera portada de la Revista Multicolor de los Sábados ilustrada por Siqueiros, aparecía sin más explicación que su propio título "Contra la corriente". Si el mural es una obra de fácil acceso al espectador, la publicación en un suplemento semanal también implicaba una distribución masiva y menos duradera que la de la obra en libro. La estridencia de los colores, el foco del título puesto en el esfuerzo de los boteros para enfrentar la ola que los amenazaba a sus espaldas, el vigor de los dos cuerpos, elemento propio del arte de Siqueiros, generan un impacto visual que convierte al lector en espectador, aspecto relevante tanto para el muralismo como para el suplemento del diario sensacionalista con un marcado interés por llamar la atención del público.

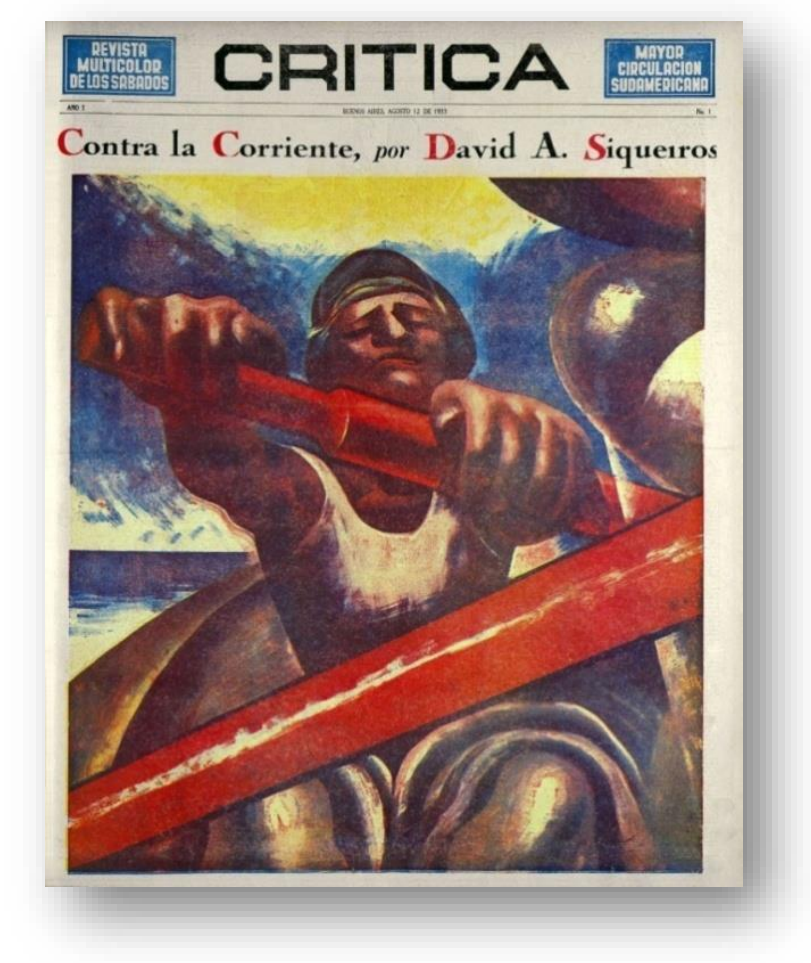

Ilustración 1. David Alfaro Siqueiros "Contra la corriente”. (12 de agosto de 1933)

Como en los murales de Siqueiros, los textos y las imágenes de la Revista Multicolor llegaban al lector sin mediación de la crítica. A diferencia de lo que ocurría en otras publicaciones periódicas de izquierda que circularon entre 1920 y 
$1930,{ }^{6}$ en el suplemento tendió a menguar la mediación cultural implicada por la crítica artística: la pintura no aparecía tanto como tema sobre el cual hablar, sino como coprotagonista del suplemento junto con la escritura.

En contraste con la selección e inclusión de reproducciones de pinturas de caballete realizada por otros medios, aquel primer ejemplar de la Revista Multicolor presentaba el trabajo del reconocido muralista. Dado que no hay registros de que esta imagen haya circulado anteriormente en otras publicaciones periódicas ni en exposiciones del artista, puede inferirse que no se trataba de una reproducción sino de una ilustración realizada por Siqueiros para el suplemento. De este modo, si la sección ilustrada del diario La Prensa, por ejemplo, presentaba en toda la superficie de su portada una gran imagen en color que reproducía una obra realizada por un artista y ya conocida en el circuito del arte, el rasgo diferencial de la Revista Multicolor fue exponer y consagrar un material visual por fuera del museo, actitud similar a la del muralismo. El suplemento se autoconfiguraba como un espacio de exposición que contrataba una pintura y le disputaba a la institución museo el lugar desde donde acceder al arte. Si el concepto "institución arte" incluye al aparato productor y distribuidor tanto como a las ideas artísticas predominantes en una época dada (Bürger 31), el suplemento adoptaba una postura anti-institucional mediante la inversión del circuito: su difusión no iba del museo o la galería a los medios sino que un concepto artístico diferente aparecía en el espacio de llegada masiva mediante técnicas que, como había propuesto el pintor mexicano, permitían dar a las obras la más amplia propagación (Siqueiros 1933).

Este tipo de inclusión y difusión de ilustraciones realizadas por un artista vinculado con la vanguardia política en el suplemento reelaboraba la propuesta de Raúl González Tuñón en su defensa a Siqueiros desde Contra y la recontextualizaba en el contexto de un diario que se autoidentificaba como representante del mundo obrero: "entreguemos al pueblo, al pueblo de la calle, nuestra obra, una obra que tenga relación con la realidad social, que interprete el

${ }^{6}$ Claridad (1926-1941), Metrópolis (1931-1932), Contra (1933), Actualidad. Económica-políticasocial. Publicación Ilustrada (1932 - 1936), Nervio (1933), entre otras. 
anhelo de los trabajadores, que son los que construyen el mundo y que son los que más derecho tienen a disponer del mundo" (González Tuñón 1933 6). No obstante, la presencia evidente de estas temáticas encarnadas en ese tipo de ilustraciones, al lado de las imágenes de mástiles, chimeneas, usinas, puertos, y de los altos muros de la ciudad que trabajaba y sufría, en la página siguiente o en la misma página, aparecía en la Revista Multicolor un universo visual muy amplio y vinculado principalmente con la fruición.

Como si se tratara de crear un mural en la revista, en cada uno de sus ejemplares la Revista Multicolor exponía una construcción colectiva en la que se ofrecían al gran público obras literarias e ilustrativas. Si Siqueiros planteaba sacar la pintura del museo, en el suplemento el libro como obra cerrada, concluida y autosuficiente era desencuadernado para participar de la creación de un mural en la revista, conformado por fragmentos de textos que se arrancaban de obras mayores e imágenes amputadas y coloreadas; se publicaban asimismo textos que en principio no estuvieron pensados como partes de libros orgánicos y que años después conformarían colecciones antológicas; se constituía como un espacio en el que muchos escritores - hasta hacía poco tiempo poetas- experimentaban con la narrativa breve y con los géneros de la prensa. La actitud "desmuseificadora" de la Revista Multicolor de los Sábados se manifestó no sólo en la difusión y exhibición de arte en sus páginas sino también en una crítica al museo a través de su ridiculización. En este sentido, la única sección fija del suplemento -“Museo de la confusión”, a cargo de Guillermo Juan Borges, quien se escondía bajo el seudónimo de Animula Vagula-, considerada como la más "vanguardista" de la Revista Multicolor por su carácter irrisorio, estuvo destinada a burlarse de los espacios que museificaban la literatura y el arte -las academias, formas de sociabilidad como los banquetes, el sector editorial. 
CATEDRAL TOMADA: Revista de crítica literaria latinoamericana / Journal of Latin American Literary Criticism El pintor que escribe en un muro de papel: David Alfaro Siqueiros en la Revista Multicolor de los Sábados (1933)

\section{David Alfaro Siqueiros: el pintor que deviene escritor}

En este espacio de difusión masiva Siqueiros participó como productor, en concordancia con su propuesta en el "Llamamiento a los plásticos argentinos”. El suplemento delimitó, no obstante, un original tipo de participación del muralista en sus páginas, vinculando los intereses políticos del artista con el carácter eminentemente fruitivo del medio. De este modo, en lugar de escribir artículos teóricos sobre el arte como en otras publicaciones periódicas contemporáneas, por primera vez, el pintor produjo textos ficcionales que, como su obra pictórica, llegaban al público sin mediaciones críticas.

Un antecedente inmediato de esta práctica puede encontrarse en la muestra llevada a cabo en abril de 1933, titulada "El violín de Ingres", promovida por la revista Signo y el grupo que le daba nombre. En esta exhibición participaron pintores que escribieron literatura y escritores que expusieron obras pictóricas. Entre los poetas que presentaron sus obras se encontraban Norah Lange, Jorge Luis Borges, Raúl González Tuñón, Oliverio Girondo, Alfonsina Storni, Leónidas Barletta, Alvaro Yunque, Peyrou, Luis Cané, Nalé Roxlo, Ulyses Petit de Murat, Pedro Juan Vignale, Cayetano Córdova Iturburu, Pablo Rojas Paz, Clodomiro Cordero; entre los pintores expusieron Xul Solar, Emilio Pettorutti, Roberto Rossi, Horacio March, Marcos Viberti, Augusto Merediz. ${ }^{7}$ Como se explicaba en Crítica:

Los que han enviado obras a ella [a la exposición] son escritores y poetas y, hasta el momento de participar en la muestra de Signo, no habían empuñado el pincel. Al mismo tiempo, la dirección de Signo, había solicitado poemas a los pintores, que se repartieron impresos anoche (los

\footnotetext{
${ }^{7}$ Algunos de estos escritores ya habían sido convocados siete años antes, en agosto de 1926, por la revista vanguardista Valoraciones para realizar una tarea similar. El artista plástico Guillermo Korn promovió el "Primer Salón de Escritores" del que participaron Oliverio Girondo, Leopoldo Marechal, Eduardo Mallea, Córdova Iturburu, Jorge Luis Borges, José Gabriel, Ricardo Güiraldes, Francisco López Merino, González Carbalho, Francisco Luis Bernárdez, entre otros. La novedad en 1933 era la interrelación entre escritores y pintores, que ahora escribían poesía.
} 
poemas, no los pintores). Para que el acto no saliera de estas singulares características se resolvió, finalmente, otorgar premios a los mejores cuadros y poemas, de acuerdo al veredicto inapelable de un jurado compuesto exclusivamente de músicos. (6, ausencia de cursivas en el original)

Las repercusiones de este intercambio pictórico-literario se hicieron presentes en la prensa periódica; Crítica comentó la noticia el 23 de abril bajo el título "Pintan cuadros los literatos, componen sonetos los pintores". Y el periódico El Mundo publicó una breve nota titulada "Dibujos de escritores" en el día 24 del mismo mes. Fiel a su estilo, el diario no se limitó a dar a conocer en sus páginas esta novedosa muestra, sino que hizo suya la idea y ensayó esa práctica en el suplemento. Es así como, además de la presencia de imágenes de reconocidos artistas y trabajadores de la ilustración argentina, uno de los aspectos más llamativos de la Revista Multicolor radicó en la publicación de relatos ficcionales a cargo de los mismos ilustradores. Esto sucedió con Parpagnoli, que publicó el breve texto "Niños" -que, junto con una profusión de imágenes apareció en la portada del número 3- y el relato "El hombre providencial”; con Pedro Rojas, que escribió los relatos "Un pleito nocturno" y "Una mirada vidriosa"; con Pascual Güida, que firmó el cuento "La última bala"; e incluso con David Alfaro Siqueiros, de quien se publicaron tres textos ficcionales. Todos los dibujantes a excepción del mexicano ilustraron sus propios textos, datos a partir de los cuales se puede interpretar el tipo de participación del muralista y caracterizar el modo en que los ilustradores concebían el vínculo entre texto e imagen.

Con respecto a Siqueiros, puede deducirse que había sido contratado no como ilustrador sino como figura relevante: su trabajo era producir un contenido original propio ya fuera pictórico o ficcional. A diferencia de las imágenes del mexicano, las de los ilustradores no tenían existencia por fuera del relato con el que se relacionaban, eran creadas a partir de él. Por otra parte, las ilustraciones de los relatos parecían incluir indicaciones sobre los aspectos textuales a los que estos 
ilustradores-autores finalmente daban relevancia y seleccionaban en el momento de producir el material visual. Los dibujos de Pedro Rojas reproducían las escenas más sensacionalistas de sus propios textos ficcionales - expresadas en la muerte de dos personajes y el descubrimiento de rasgos físicos monstruosos-; Güida ponía el foco en la fisonomía de los personajes que protagonizaban el cuento que había escrito; Parpagnoli, en cambio, elegía escenas más generales y descriptivas -niños jugando en una plaza, gente esperando un colectivo--, que se enfocaban más en el contexto de las historias que en los acontecimientos narrados.

Mientras en el cuerpo del diario se difundían los textos teóricos y se ponían en evidencia las relevantes redes intelectuales forjadas entre el artista mexicano y sus pares argentinos, el suplemento pretendió acercar su arte al público masivo sin mediaciones críticas pero con los condicionamientos propios de una empresa periodística. Siqueiros publicó en la Revista Multicolor dos textos narrativos, "Siete Filos" (19/08/1933), ilustrado por Rechain y "El derrumbe del coraje”, con dibujos de Pedro Rojas (30/09/1933) y un poema en prosa, "Trópicos", con imágenes a cargo de Andrés Guevara (09/12/1933). En relación con estas colaboraciones se vuelve relevante indagar qué características tuvieron estos textos en el contexto del suplemento, principalmente si mantuvieron algún vínculo con las temáticas del diario, qué relaciones establecieron con las ideas expuestas por el artista en sus conferencias, qué rol jugaron las imágenes que los acompañaron.

La Revista Multicolor de los Sábados difundía, al mismo tiempo que condicionaba, la obra del autor, de acuerdo con sus particularidades de publicación: por primera vez el artista escribía textos literarios ilustrados a todo color. En éstos se retomaban algunas de las temáticas de sus obras tales como la violencia, la exposición y tortura del cuerpo, así como la presencia del color como elemento fundamental en la construcción y en la descripción de las escenas, que vinculaba los relatos con los recursos propios de su poética pictórica. En las tres producciones escritas el escenario era México, su país de origen; en todas ellas se observa un cruce entre elementos literarios, elementos propios de este diario masivo e imágenes sensoriales. Entre estos elementos se conjugaba el carácter anecdótico 
que tomaban las historias, la convivencia de los textos con otros de temáticas similares, la presencia del color en el interior mismo de las ficciones y en conjunción con la posibilidad técnica de la impresión, todos los cuales ponían en tensión la producción del artista y los condicionamientos de la prensa.

Un primer aspecto que puede asociarse con una insistencia de la Revista Multicolor fue la escritura de textos principalmente narrativos en los que el relato se construía a partir de la estructura de anécdota. Esto puede vincularse con el importante componente fruitivo del suplemento, destinado al entretenimiento sabatino de la familia argentina, como lo remarcaban sus anuncios publicitarios. "Siete Filos", que aparecía en el segundo número (19 de agosto de 1933), narraba en primera persona la anécdota de cómo, siendo niño, el pintor mexicano había presenciado la matanza de una de sus mascotas más queridas: su perro, apodado "el Diablo". El animal, que se encontraba infectado por la rabia, había muerto en las manos de su abuelo, el coronel don Antonio Alfaro Sierra. ${ }^{8}$ El relato se encontraba acompañado por una imagen central realizada por Rechain, en la que podía verse al jinete "Sietefilos" alzando su machete para pegarle al perro de la casa mientras de fondo, un muchacho en su caballo observaba la escena. La ilustración reforzaba el coraje y la violencia del jinete, su dominio por sobre otros seres vivientes. Estas dos particularidades, así como el título apelativo vinculaban temáticamente la narración con la serie "Historia Universal de la Infamia" de Borges, con uno de cuyos relatos compartió página -"Eastman, el proveedor de iniquidades”-. En esta imagen, que imita la estética del cómic, el dinamismo de las figuras centrales contrasta con el jinete del fondo que, en una actitud pasiva similar a la del narrador testigo del texto, observa la escena.

${ }^{8}$ Dice Siqueiros al comenzar su historia: "Sietefilos [apodo que le daban a su abuelo] es mi más lejano recuerdo y sin embargo tan nítido como el más reciente" (RMS 1933 7). 


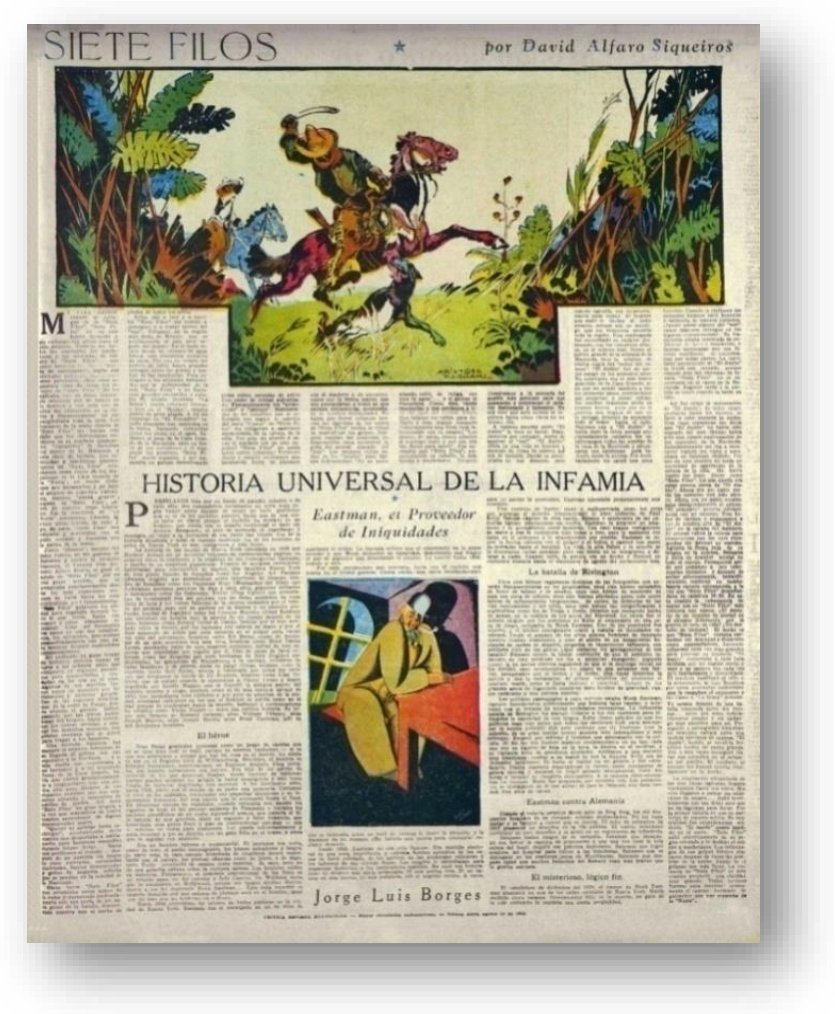

Ilustración 2. David Alfaro Siqueiros. "Siete Filos"

(19 de agosto de 1933)

El segundo de los relatos publicados por Siqueiros en la Revista Multicolor se titula "El derrumbe del coraje" y aparece en el número 8 (30 de septiembre de 1933). En él, nuevamente, hay un narrador en primera persona que, en este caso, cuenta los acontecimientos acaecidos una noche de 1916, en una época definida como "la más violenta [...] de la revolución mexicana" (5). Como teniente oficial del Estado Mayor en Guadalajara, el narrador, junto con otros dos compañeros, había encontrado y detenido un individuo sospechoso, quien resultó ser el coronel villista José Isabel Izunza, miembro de la división del norte que tenía en mente dinamitar los trenes de la división a la que pertenecía quien relataba la historia. Acto seguido, encerraron a Izunza y lo condenaron al fusilamento. El texto se detenía en dos momentos: en el primero, el condenado se encontraba con su esposa en la cárcel y, en el segundo, era llevado para ser ejecutado. El narrador dejaba en claro una diferencia crucial entre esas dos instancias relacionadas con dos estados 
de ánimo: el coraje del preso mientras se encontraba en la celda y la cobardía que lo asaltó antes de ser fusilado.

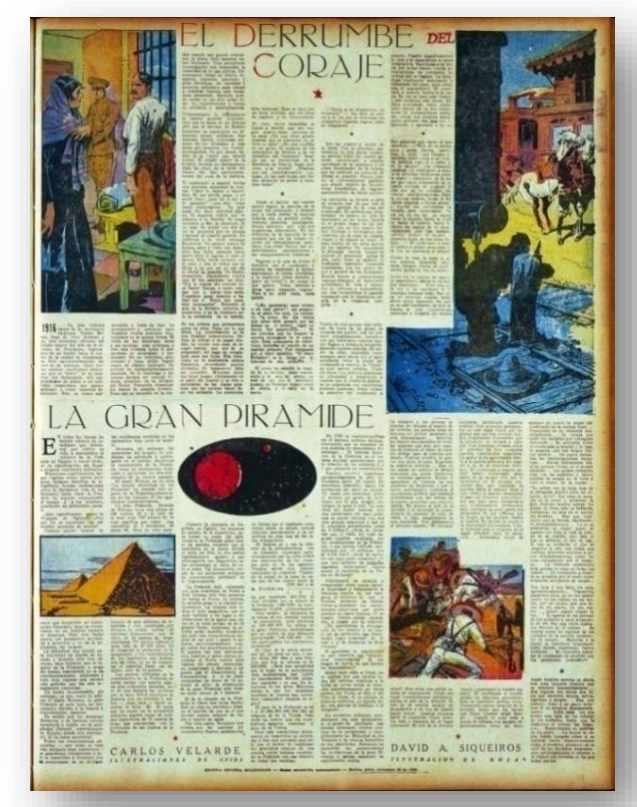

Ilustración 3. David Alfaro Siqueiros. "El derrumbe del coraje".

(30 de septiembre de 1933)

Este texto se encuentra acompañado por tres imágenes a cargo de Pedro Rojas que, como en otras de sus ilustraciones, representan las escenas más sensacionalistas de la historia narrada: a la izquierda, el dibujo muestra al protagonista en la cárcel donde había sido detenido. Como en la ilustración de "Siete filos", en esta se veía al fondo a un personaje testigo, que podemos identificar con el narrador, el coronel que contaba cómo había presenciado esa escena. A la derecha del relato, otra ilustración mostraba un momento anterior al del encuentro de la pareja: aquel en el que Izunza había sido encontrado por el narrador y sus compañeros, a punto de dinamitar un tren. Esta imagen es profusa en detalles sobre las armas y la posición de los cuerpos. Más abajo, y más pequeño, aparecía un dibujo que representaba una de las escenas más dramáticas del texto: aquella en la que el hombre que iba a ser fusilado se aferraba a su esposa y era apartado de ella a la fuerza por quienes iban a ejecutarlo. El modo en que los dibujos que 
acompañaron al texto ficcional mostraban a los personajes siempre de espaldas, y especialmente esta última en la que los participantes de la escena se encontraban concentrados en su tarea, como si hubieran sido fotografiados en pleno ataque, posicionaban al lector como espectador.

Aunque en estos relatos no se hicieron presentes las ideas sobre la función social del arte que el muralista había expuesto en otros espacios, sí hacían referencia a momentos de fuerte tensión política y representaban la violencia que vivía México a comienzos del siglo XX. El pintor devenido escritor se adaptaba a los requisitos que imponía el medio publicando historias anecdóticas de un narrador testigo, cuyo principal motor era el coraje, sin dejar de lado la dimensión política. Asimismo, al recurrir a formas de representación más estilizadas y convencionales, los dibujos transformaban el sentido del texto.

Un segundo aspecto que caracterizó a los cuentos de Siqueiros fue la proliferación de descripciones, compuestas por una gran cantidad de adjetivos que les daban densidad no sólo visual sino también sensorial lo cual generaba una competencia del contenido textual con las imágenes que lo acompañaban. En algunos casos, predominaba el sentido del oído, como sucedía en "El derrumbe del coraje" donde se relataba:

El condenado a muerte vuelve a gritar, pero esta vez su voz es quebrada y sibilante, perdió la otra, la otra que era pastosa, amasada, cálida, dura, integra. Ahora inmortalmente aguda, su voz es chillona. Antes fue de macho, de caporal, de guerrillero, ahora es de hembra suplicante. (5)

Esta particularidad sonora aparecía, asimismo, en la voz de las mujeres indias que acompañaban al condenado, de quienes se decía que en el momento en que aquel iba a ser fusilado: "ya no sollozan sino braman compulsivamente" (5). Más adelante, la historia de Siqueiros se enfocaba en los movimientos del cuerpo: "Pero más que la voz, [al condenado] le ha cambiado la estructura humana toda. Sus ojos ya no ensartan cuando miran, ahora miran lamiendo. Su cuerpo está 
hundido, se está doblando, se está constriñendo, empiezan a colgarle los brazos” (5, cursiva mía). Al ver a su mujer por segunda vez, la escena se volvía mucho más cruel:

Hay que separarlos por la fuerza, rápidamente, despiadadamente. Ya no es solamente la mujer quien se agarra con toda la vida al cuerpo de su marido, sino éste el que se adhiere, el que se liga, el que se embarra, el que se retuerce a ella con todas sus fuerzas, mientras empieza a gemir desoladoramente. (5)

Las imágenes sensoriales evidenciadas en la proliferación de verbos y adjetivos, que generaban una representación más vívida de la historia y que ponían el foco sobre los personajes sufrientes, pueden relacionarse con los recursos que ya estaban presentes en la obra pictórica de Siqueiros y que su producción escrita retomaba: los gritos -en el mural "Un mitín obrero" (1932)-, las torturas -que conformaron la escena principal del fresco “Tropical América” (1934)-, el detalle en la representación de los cuerpos y sus movimientos, presente en numerosos murales del artista mexicano.

Las imágenes que acompañaban los textos ficcionales recuperaban también esa lucha corporal, como se observa en la pequeña ilustración que aparecía casi al final de la historia de "El derrumbe del coraje" y en la única imagen que ilustraba "Siete Filos". Ésta última tomaba como motivación una escena presente el relato en la que se detallaba la pelea de tres cuerpos, el de un perro con rabia, el del abuelo de Siqueiros y el del caballo. La ilustración de este último cuento reproducía el movimiento que describía el texto:

El machete sustituyó al rifle y la persecución se hizo frenética por entre punzantes matorrales [...]. Yo estaba frente a una batalla tremenda entre dos fuerzas, entre dos seres indudablemente crueles y sin embargo muy queridos por mí. Perseguido y perseguidor formaban un remolino salvaje 
entre una maleza hiriente de espinas. El diablo, herido, se revolvía frenético contra mi padre grande. [...] El machete, al romper los huesos sonaba ríspidamente en la noche [...]. Mis ojos llegaron a palpitar las salpicadas de sangre. (7)

Las escenas en las que los cuerpos se sacudían, se batían, se estremecían fueron las que Rechain y Rojas, los ilustradores de estos cuentos, eligieron mostrar a los lectores, decisión que otorgaba un rasgo de mayor dinamismo al relato.

Un tercer elemento fundamental fue la presencia del color en el interior mismo del texto. Tanto las narraciones como el poema en prosa hicieron referencia a tonalidades que algunas veces coincidían y otras no con las de las ilustraciones. Esto se hace evidente principalmente en el poema en prosa que se publica en el número 18 del suplemento bajo el título "Trópicos", encajonado entre dos guardas ornamentales a cargo de Andrés Guevara, que representaban una parte del paisaje descrito.

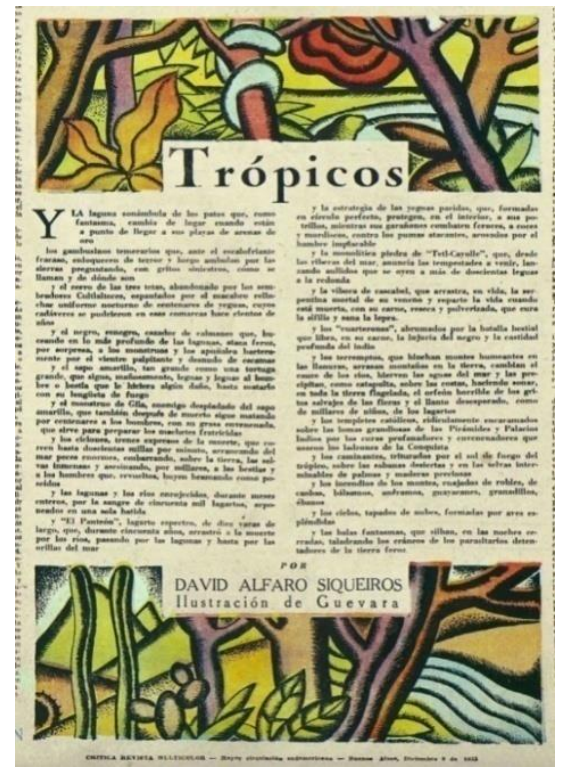

Ilustración 4. David Alfaro Siqueiros. "Trópicos" [detalle]

(9 de diciembre de 1933) 
Ésta fue la más visual de las producciones narrativas que artista mexicano publicó en la Revista Multicolor, en ella se presentaba una sucesión de escenas del trópico, compuesta por plantas, fenómenos naturales y animales, organizada en versos que comenzaban con el coordinante " $y$ ", generando una cadena hilada por una sucesión de descripciones eslabonadas a partir de este nexo. En el poema predominaron las imágenes visuales de los seres que habitaban un espacio selvático en negro, rojo, amarillo, marrón, y que se repitieron en algunas partes de la ilustración. El texto afirmaba que de color "negro renegro" era el cazador de caimanes que habitaba allí, que también había un "sapo amarillo, tan grande como una tortuga grande", y que las lagunas y los ríos se habían enrojecido durante meses enteros "por la sangre de cincuenta mil lagartos arponeados en una partida"; que los caminantes que pasaban por ahí eran "triturados por el sol del fuego del trópico sobre las sabanas desiertas", y que los indios de los montes tenían colores "cuajados de robles, de caobas, bálsamos, ameramos, guayacanes, granadillos, ébanos" (6). La imagen que ilustraba el texto lo enmarcaba, separándolo del resto de la página, y reproducía el paisaje selvático descrito por el poema.

Ese mismo trabajo visual con el color puede encontrarse en "Siete Filos", donde el rojo y el negro predominaban -generando tensión dramática- como los colores del pelo del caballo que montaba el coronel Alfaro: "Mi abuelo montaba la brasa, yegua colorida, retinta, o bien el mojino, caballo prieto de gran alzada" (7). De un "negro profundo hasta los dientes" era también el color del pelaje del Diablo, el perro del protagonista infestado por rabia y que, en la batalla con su abuelo, trazaba "violentamente una línea roja interminable con su sangre" (7). Del mismo modo, "El derrumbe del coraje" presentaba la imagen del condenado arrastrándose "como serpiente enrojecida de sangre", hombre que al final del relato y ya en sus últimos minutos de vida terminaba siendo visto como "una cosa chiquita, oscura, que se retuerce asquerosamente" (6). Esta particularidad relaciona la producción escrita con la estética del artista mexicano en la que predominaban los colores saturados. La publicación de estos textos en un suplemento ilustrado 
completamente a color (una novedad para la época), robustecía esta característica y la orientaba hacia una lectura fruitiva.

La participación de Siqueiros en el suplemento estuvo marcada por la disminución de lo político, un aspecto fundamental en la propuesta que el artista llevó a Argentina y al resto de los países en los que pasó su exilio. La Revista Multicolor de los Sábados se apropió de la idea de ofrecer el mejor arte al más amplio público y la resemantizó en una estrategia de venta. Por otro lado, esta publicación periódica difundió, al mismo tiempo que condicionó, la obra del autor, de acuerdo con sus particularidades de publicación: por primera vez el artista escribe textos literarios que fueron ilustrados a todo color. Ellos retomaron algunas de las temáticas de sus obras (la violencia, la exposición y tortura del cuerpo), así como la presencia del color como elemento fundamental en la descripción de las escenas. Mientras en el cuerpo del diario se difundían los textos teóricos y se ponían en evidencia las relevantes redes intelectuales forjadas entre el artista mexicano y sus pares argentinos, el suplemento acercó su arte al público masivo sin mediaciones críticas pero con los condicionamientos propios de una empresa periodística.

\section{Bibliografía}

\section{Corpus de análisis:}

Alfaro Siqueiros, D. "Um llamamiento a los Plásticos Argentinos”. Crítica, Buenos Aires, 2 de junio de 1933, p. 7.

. "Siete Filos". Revista Multicolor de los Sábados, 2 (1933): 7

. "El derrumbe del coraje”. Revista Multicolor de los Sábados, 8 (1933):

5

. “Trópicos”. Revista Multicolor de los Sábados, 18 (1933): 6 


\section{Bibliografía crítica:}

$\mathrm{S} / \mathrm{N}$ "Pintan cuadros los literatos, componen sonetos los pintores". Crítica, Buenos Aires, 23 de abril de 1933, p.6.

S/N "Dibujos de escritores" El Mundo, 24 de abril de 1933, p. 6

Azuela de la Cueva, A. "Militancia política y labor artística de David Alfaro Siqueiros: de Olvera Street a Río de la Plata”. Estudios de historia moderna y contemporánea de México, número 35, enero-junio de 2008, pp. 109 - 144.

Bürger, Peter. Teoría de la vanguardia. Buenos Aires: Las Cuarenta, 1974.

González Tuñón, R. "D. Alfaro Siqueiros y los 'Próximos-Pasados”. Contra. La revista de los francotiradores, 3, julio de 1933.

Martín- Barbero, J. “De las masas a la masa”. En: De los medios a las mediaciones. Comunicación, cultura y hegemonía. Barcelona- México: G.Gili, 1991

Martínez Quijano, Á. Siqueiros: muralismo, cine y revolución. Buenos Aires: Ediciones Lariviére.

Mascioto, M. Á. “Guillermo Facio Hebequer en la Revista Multicolor de los Sábados: Articulaciones entre arte social y prensa masiva” Actas del IX Congreso Internacional Orbis Tertius. La Plata: Universidad Nacional de La Plata, 2015.

- "Nuevas formas de visualidad en los años treinta: La literatura y la imagen en la Revista Multicolor de los Sábados". Actas del IV Coloquio Internacional Literatura y Vida. Rosario: Celarg, 2016

Melot, M. "Le texte et l'image”. En : Chartier, Roger et Henri-Jean Martin, director. Histoire de l'édition française. Le temps des éditeurs. Du romantisme a la Belle Époque. Tomo III, París: Fayard/Promodis, 1990

Szir, S. "Entre el arte y la cultura masiva. Las ilustraciones de la ficción literaria en Caras y Caretas (1898 - 1908)". En: Malosetti, Laura y Marcela 
CATEDRAL TOMADA: Revista de crítica literaria latinoamericana / Journal of Latin American Literary Criticism

El pintor que escribe en un muro de papel: David Alfaro Siqueiros en la Revista Multicolor de los Sábados (1933)

Gené. Impresiones porteñas: imagen y palabra en la historia cultural de

Buenos Aires. Buenos Aires: Edhasa, 2009 